\title{
Optimization of extrusion process varibles for preparation of vitamin C enriched ready-to-eat product from maize-rice- aonla using response surface methodology
}

\author{
-G.S. CHIKKANNA*, D.V.K. SAMUEL ${ }^{1}$ and S.K. JHA
}

Division of Post Harvest Technology, Indian Agricultural Research Institute, NEW DELHI (INDIA)

Email : chiksiari@gmail.com

${ }^{1}$ Division of Agricultural Engineering, Indian Agricultural Research Institute, NEW DELHI (INDIA)

*Author for Correspondence

Research chronicle : Received : 28.01.2014; Revised : 13.04.2015; Accepted : 25.04.2015

\begin{abstract}
SUMMARY :
Response surface methodology (8.0.7.1) was employed to study the optimization of process variables of extrusion technology i.e. die temperature, Screw speed and feed moisture content. A ready to eat extruded food was developed by using a twin screw extruder. A nutritious ready to eat expanded product based on maize grits, rice flours and aonla was developed for school going children (6-16 years). Feed moisture content was found to have maximum influence on bulk density whereas the screw speed and die temperature had maximum influence on colour and expansion ratio of the product, respectively. Blends of maize grits, rice flours and aonla $(80: 10: 10)$ were used as the ingredients for extrusion that would provide the vitamin $\mathrm{C}$ requirement of the targeted population with a minimum cost. Based on organoleptically evaluation, product extruded at processing conditions of $125^{\circ} \mathrm{C}$ die temperature, 310 screw rpm and 22 per cent (d.b) feed moisture content was found to be most acceptable quality extruded product.
\end{abstract}

KEY WORDS : Bulk density, Moisture content, Expansion ratio, Hardness, Colour, Extrusion

How to cite this paper : Chikkanna, G.S., Samuel, D.V.K. and Jha, S.K. (2015). Optimization of extrusion process varibles for preparation of vitamin $\mathrm{C}$ enriched ready-to-eat product from maize-rice-aonla using response surface methodology. Internat. J. Proc. \& Post Harvest Technol., 6 (1) : 26-35. 